可視化情報 Vol.21 Suppl. No.2（2001 年 9 月）

\title{
B114＼cjkstart先細ダクトにおける複合圧縮流れの可視化
}

\author{
与那嶺 牧子○ (九大院), 權 眞卿(九大院), 宮里 義昭 (九大) \\ 片野田 洋（北九大），益田 光治（九大）, 松尾 一泰（九大）
}

\section{Visualization of Compound Compressible Flows in Converging Ducts}

\author{
Makiko YONAMINE, Jin-Kyung, KWON, Yoshiaki MIYAZATO,
}

Hiroshi KATANODA, Mitsuharu MASUDA, and Kazuyasu MATSUO

\begin{abstract}
The compound choking phenomena by confluence of two subsonic streams flowing in the same converging duct were experimentally investigated by the optical observations as well as the pressure measurements. A criterion for the compound choking is shown and discussed. Also, the experimental data are compared with the results calculated by using an inviscid onedimensional model.
\end{abstract}

Keywords: Compressible Flow, Comnpound Choking, Converging Duct, Schlieren Method

\section{1. まえがき}

単一の気体が先細ノズルを通って背圧まで膨張する場 合の閉塞については, 一次元的取り扱いが確立されてい る ${ }^{1}$. 一一方, 速度の異なる二つの流れが先細ノズルに平 行に流入して背圧まで膨張する場合も，二つの流れの貯 気圧を一定にし, 背圧をある圧力まで下げると閉塞する. このような流れの閉塞を複合閉塞 ${ }^{2)}$ といい, 単一流れの 閉塞とは異なる特徵を示す. 本研究は, 先細ダクトを通 る二つの亜音速流れによって生じる複合閒塞をシュリー レン法による可視化と圧力測定によって調べた. 特に, 複合閉塞が起こる条件を実験的に明らかにしたので，そ の結果について報告する.

\section{2. 実験装置と方法}

実駼装置の模式図を図 1 に示す，二つの圧縮機によつ てそれぞれの貯気槽に蓄えられた高圧の乾燥空気は，上 部及び下部の手動バルブを通ってよどみ状態になり, ダ クト入口で合流し, 先細ダクト, 一定断面積ダクト, 後 部集合洞を経て大気へ開放される.ダクト入口の高さは, 上部, 下部ともに $20 \mathrm{~mm}$, ダクトの長さは $155 \mathrm{~mm}, タ ゙$ クト出口高さは $20 \mathrm{~mm}$ で, ダクトの上壁と下壁は入口 から出口まで直線壁となっている．また測定部の幅はす ベて $80 \mathrm{~mm}$ である. 図 1 に示す破線部分は, シュリー レン法による流れの可視化のための光学ガラスの範囲を 示す. 圧力測定は, ダクト上流の上部集合洞のよどみ圧 力 $\mathrm{p}_{01}$ と下部集合洞のよどみ圧力 $\mathrm{p}_{02}$ 及びダクト出口の
静圧 $p_{e}$ の 3 点で行った.

\section{3. 実験結果と考察}

\section{1 流れの可視化}

先細ダクト上流の上部集合洞のよどみ圧力 $\mathrm{p}_{01}$ に対す る下部集合洞のよどみ圧力 $\mathrm{p}_{02}$ の比 $\phi\left(\equiv \mathrm{p}_{02} / \mathrm{p}_{01}\right)$ が 0.9 のときの先細ダクト内の流れ場を図 2 に示す. ただし， ナイフエッジの向きは流れ方向に垂直である. 3.2 節で 述べる複合閉塞の条件を考慮すると, 図 2(a)の流れは複 合閉塞しておらず, 図 2(b)の流れは複合閉塞している. すなわち, 複合閉塞している流れでは, 先細ダクト出口 下流にほほ上下対称な衝撃波が観察される.

\section{2 複合閉塞の条件}

$\mathrm{p}_{01}$ と後部集合洞の圧力 $\mathrm{p}_{\mathrm{a}}$ の比 $\mathrm{p}_{01} / \mathrm{p}_{\mathrm{a}}$ と先細ダクト出 口静圧 $\mathrm{p}_{\mathrm{e}}$ に対する $\mathrm{p}_{01}$ 及び $\mathrm{p}_{02}$ の比 $\mathrm{p}_{01} / \mathrm{p}_{\mathrm{e}}, \mathrm{p}_{02} / \mathrm{p}_{\mathrm{e}}$ の関係 を図 3 に示す. ただし $\phi=0.9$ であり, 図中の(a)と(b)は, 図 2 の(a)之(b)の写真の条件にそれぞれ対応する. $\mathrm{p}_{01} / \mathrm{p}_{\mathrm{a}}$ が約 1.75 まで增加するにつれ $\mathrm{p}_{01} / \mathrm{p}_{\mathrm{e}}$ と $\mathrm{p}_{02} / \mathrm{p}_{\mathrm{e}}$ はそれぞれ 約 1.9 と 1.7 まで直線的に增加するが, これよりさらに $\mathrm{p}_{01} / \mathrm{p}_{\mathrm{a}}$ が增加すると, 図 3 の右側の縦軸に左向き矢印で 示すように, $\mathrm{p}_{01} / \mathrm{p}_{\mathrm{e}}$ と $\mathrm{p}_{02} / \mathrm{p}_{\mathrm{e}}$ は, $\mathrm{p}_{01} / \mathrm{p}_{\mathrm{a}}$ にほとんご無関係 にそれぞれ $\left(\mathrm{p}_{01} / \mathrm{p}_{\mathrm{e}}\right)_{\mathrm{ch}}=$ 約 1.96 と $\left(\mathrm{p}_{\mathrm{O}_{2}} / \mathrm{p}_{\mathrm{e}}\right)_{\mathrm{ch}}=$ 約 1.74 の一 定値となる、これは先細ダクト上流の流れが先細ダクト 下流の流れ場と独立になり, 流れが複合閉塞しているこ とを示す. 複合閉塞したときの圧力比 $\left(\mathrm{p}_{01} / \mathrm{p}_{\mathrm{e}}\right)_{\mathrm{ch}}$ と $\left(\mathrm{p}_{02} / \mathrm{p}_{\mathrm{e}}\right)_{\mathrm{ch}}$ の $\phi$ に対する変化を図 4 に示す. 実線は非粘性一次元理 論による計算値を示す ${ }^{22}$. 計算值と実験値は, $\phi$ が約 0.8 
以上ではほぼ一致しているが， $\phi$ が約 0.8 以下では二つ の流れの混合の影響によってずれてくる.

\section{4.あとがき}

先細ダクトを通る二つの亜音速流れの合流によって生 じる複合閏塞を実験的に調べた. その結果, 流れが複合 閉塞するときには先細ダクト下流に，ほぼ上下対称な衝 撃波が観察されることがわかった. また複合閉塞すると
きの先細ダクト上流のよどみ圧力と先細ダクト出口静圧 の関係を実験的に明らかにした。

\section{考 文 献}

1) 松尾一泰：圧縮性流体力学, (1994) p.65, 理工学社

2) Bernstein, A., Heiser, W. H. , and Hevenor, C. : CompoundCompressible Nozzle Flow, Trans.ASME,J.Applied Mechanics, Vol.34, (1967) p.550.

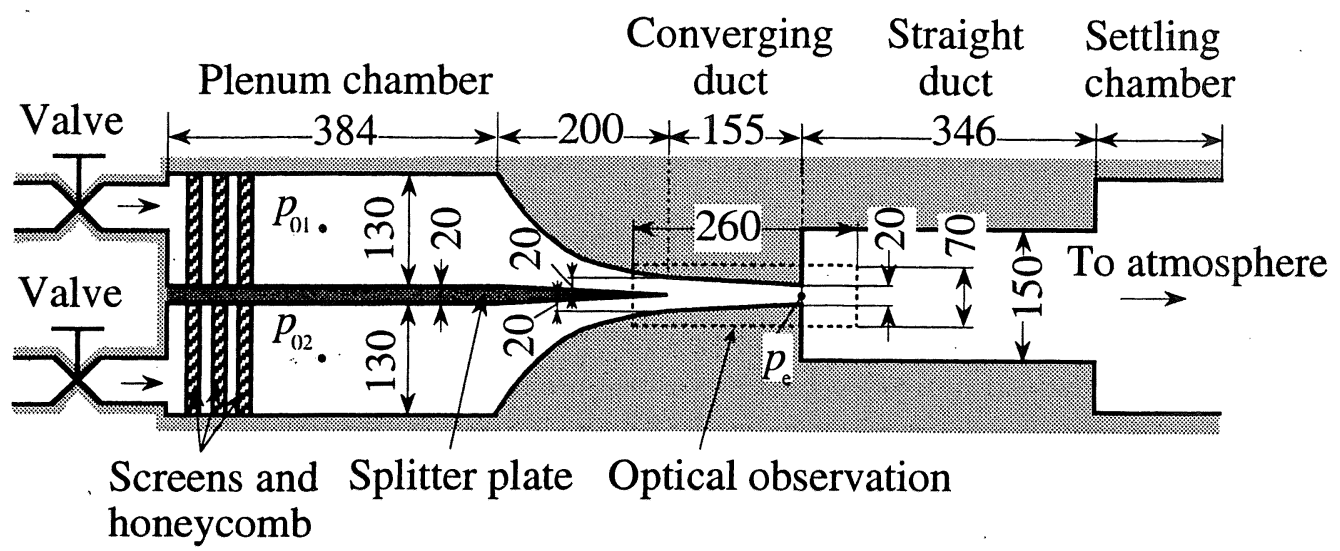

Fig.1 Schematic of experimental apparatus

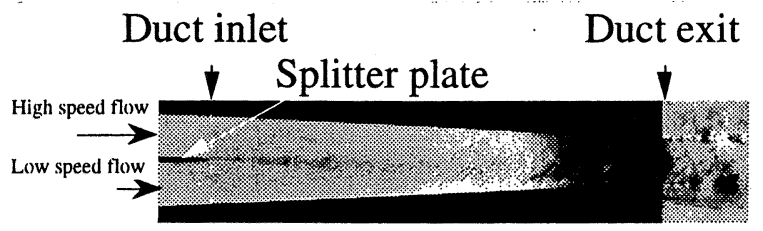

(a) $p_{01}=170 \mathrm{kPa}, p_{02}=153 \mathrm{kPa}$

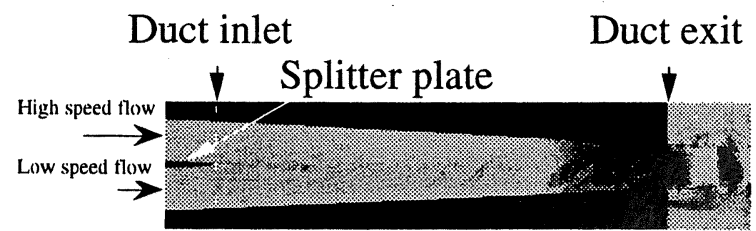

(b) $p_{01}=200 \mathrm{kPa}, p_{012}=180 \mathrm{kPa}$

Fig.2 Typical schlieren photographs of compound compressible duct flows, $\phi=0.9$

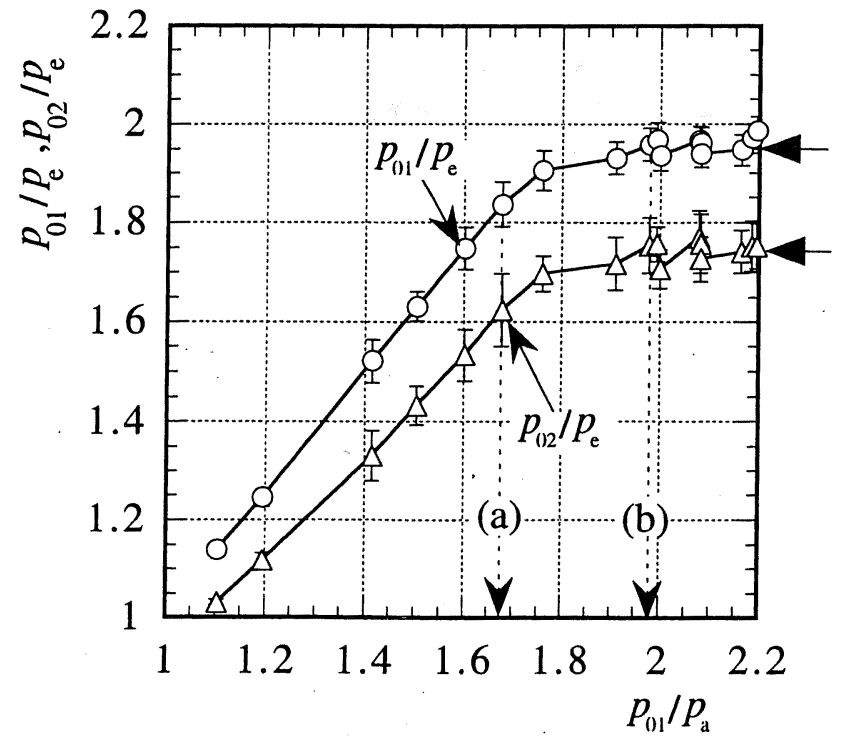

Fig.3 Relationship between plenum pressures and static pressure at duct exit ( $\phi=0.9$ )

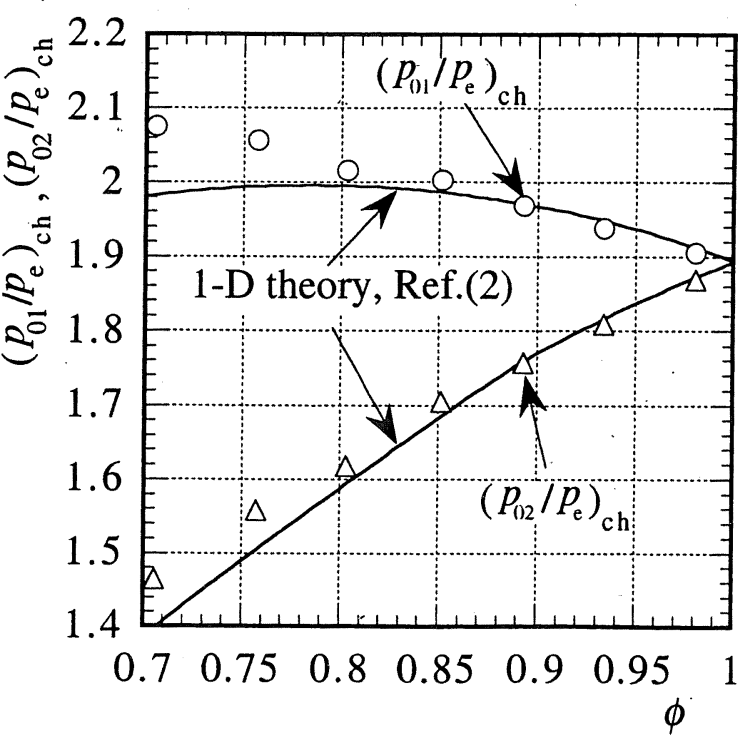

Fig.4 Compound choking conditions 